\section{Self-incompatibility Alleles of Apple Cultivars and Advanced Selections}

\author{
Kenji Sakurai $^{1}$, Susan K. Brown ${ }^{2}$, and Norman Weeden ${ }^{2}$ \\ Department of Horticultural Sciences, Cornell University, New York State \\ Agricultural Experiment Station, Geneva, NY 14456-0462
}

Additional index words. Malus $\times$ domestica, polymerase chain reaction

\begin{abstract}
The $S$-alleles of 55 apple (Malus $\times$ domestica Borkh.) cultivars and selections were determined using an allele-specific polymerase chain reaction (PCR) amplification system for 11 different $S$-alleles $(S 2, S 3, S 4, S 5, S 7, S 9, S 24, S 26, S 27, S d, S f)$. Four cultivars had $S$-alleles different than those predicted by their parentage. Three commercial cultivars of unknown pedigrees had $S$-genotypes that suggested 'Delicious' and 'Golden Delicious' were the parents. $S$-genotyping results supported controlled pollination test results. The genotypes of the five triploid cultivars examined were consistent with the unreduced gamete being contributed by the female parent. Although a large number of $S$-genotypes is available in apple, artificial selection or repeated use of the same cultivars as parents appears to have significantly restricted the number of compatibility groups associated with commercial clones. In controlled reciprocal crosses between two cultivars of known $S$-genotypes, the segregation of $S$-genotypes and $S$-alleles was $1: 1: 1: 1$, the ratio expected for random pairing of alleles.
\end{abstract}

Apple has a multi-allelic gametophytic incompatibility system controlled by a single $S$ gene (Frankel et al., 1977; Kobel et al., 1939). In order to produce commercial crops, most commercial cultivars must be grown with another cultivar or crabapple as a pollinizer. However, limited knowledge about the $S$-genotypes of commercial cultivars makes the selection of compatible pollinizers difficult.

Some apple cultivars are known to be crossincompatible (Ishiyama et al., 1995; Way, 1995). Specific $S$-alleles have been designated on the basis of pollination tests (Kobel et al., 1939; Komori et al., 1996), isozyme markers (Batlle et al., 1995; Manganaris and Alston, 1987), and $S$-glycoprotein profiles (Sassa et al., 1994). However, these methods are timeconsuming, and environmental effects often make the results difficult to interpret.

Janssens et al. (1995) developed a molecular technique for $S$-allele genotyping in apple using an allele-specific polymerase chain reaction (PCR) amplification, followed by re-

Received for publication 27 Aug. 1998. Accepted for publication 12 May 1999. This research was supported in part by Hatch funds and by a grant from the USDA NRICRG 93-37388-8776. We gratefully acknowledge Dr. W. Broothaerts, Centre for Fruit Culture, Katholieke Universiteit, Leuven, Belgium, for information on primers and helpful discussions during the course of this work. We also thank David Terry for his assistance and Warren Lamboy and Bill Johnson for their review of this manuscript. From a dissertation submitted by K.S. in partial fulfillment of the requirements for the $\mathrm{PhD}$ degree at Tokyo Univ. of Agriculture and Technology. The cost of publishing this paper was defrayed in part by the payment of page charges. Under postal regulations, this paper therefore must be hereby marked advertisement solely to indicate this fact.

${ }^{1}$ Present address: Lab, Horticultural Science, Tokyo Univ. of Agriculture and Technology, 3-5-8 Saiwaicho, Fuchu, Tokyo, Japan 183-8509.

${ }^{2}$ To whom reprint requests should be addressed. E-mail: skb3@ cornell.edu

$S 2, S 3, S 5$,

$S 7$, and $S 9^{u}$ of 241 and 37 base pairs. and Sakurai et al. (1997). genotyped further. Furthermore, cultivars and advanced selections useful in genetic improvement and cultivars of commercial interest were subjected to PCR analysis to determine their $S$-genotypes. The distribution of $S$-alleles among commercial cultivars and advanced selections was also analyzed. Finally, we examined the segregation of $S$-genotypes in progenies of reciprocal crosses between 'Golden Delicious' (S2S3) and 'Jonathan' (S7S9) to determine whether certain $S$-alleles had a selective advantage.

\section{Materials and Methods}

Plant material was obtained from collections at the New York State Agricultural Experiment Station and the U.S. Dept. of Agriculture's Plant Genetic Resources Unit in Geneva, N.Y. Extraction of DNA and the allele-specific PCR for $S 2, S 3, S 5, S 7$, and $S 9$ were as described by Janssens et al. (1995) and modified by Sakurai et al. (1997). Procedures for $S 4, S 24, S 26$, and $S 27$ were as described by Verdoodt et al. (1998) (Table 1). Another set of primers for $S 24$ were designed based on information provided by GenBank (AF016920). Primers for the $S \mathrm{~d}$ - and $S$ f-alleles were based on the Sd-RNase I cDNA from 'Delicious' (Katoh et al., 1997) and the Sf cDNA from 'Fuji' (Sassa et al., 1996), respectively (Table 1).

Each $35 \mu \mathrm{L}$ PCR mixture contained $50 \mathrm{~mm}$ $\mathrm{KCl}, 10 \mathrm{~mm}$ Tris- $\mathrm{HCl} \mathrm{pH}$ 9.0, 0.1\% Triton $\mathrm{X}$ $100,2 \mathrm{~mm} \mathrm{MgCl}_{2}, 200 \mu \mathrm{m}$ of each dNTP, $1 \mu \mathrm{M}$ of each primer, 0.875 unit of Taq polymerase (Promega, Madison, Wis.), and $50 \mathrm{ng}$ template DNA. Amplification was performed in a PTC-100 Programmable Thermal Controller (MJ Research, Inc., Watertown, Mass.) programmed for 30 cycles of denaturation ( $1 \mathrm{~min}$ at $\left.94{ }^{\circ} \mathrm{C}\right)$, annealing $(1 \mathrm{~min}$ at an optimal temperature for each primer combination)

Table 1. Oligonucleotide sequences and conditions for allele-specific polymerase chain reaction (PCR).

\begin{tabular}{|c|c|c|c|c|c|}
\hline$S$-allele & Primers & $\begin{array}{c}\text { Sense/ } \\
\text { antisense }\end{array}$ & $\begin{array}{l}\text { Nucleotide sequence } \\
\qquad\left(5^{\prime} \rightarrow 3^{\prime}\right)\end{array}$ & $\begin{array}{l}\text { Annealing } \\
\text { temp }\left({ }^{\circ} \mathrm{C}\right)\end{array}$ & $\begin{array}{l}\text { Size (bp) } \\
\text { of PCR } \\
\text { products }\end{array}$ \\
\hline \multirow[t]{2}{*}{$\overline{S f^{2}}$} & FS1 & Sense & caatcgaaacgatcatgaag & 62 & 493 \\
\hline & FA1 & Antisense & tccgtgtataggccatcgac & & \\
\hline \multirow[t]{2}{*}{$S \mathrm{~d}^{\mathrm{y}}$} & DS2 & Sense & atcgaactgatcatgtaggc & 62 & 355 \\
\hline & DA1 & Antisense & tatcgtgaaccttgtggtgg & & \\
\hline \multirow[t]{2}{*}{$S 4$ and $S 27^{\mathrm{x}}$} & FTC5 & Sense & atgaattcccacaatacagacgaga & 58 & $278^{\mathrm{w}}$ \\
\hline & OWB249 & Antisense & atgaattcaatctatgaaatgtgctctg & & \\
\hline \multirow[t]{2}{*}{$S 24 \mathrm{a}^{\mathrm{x}}$} & OWB234 & Sense & atgaattcggatcctccgacaagttggtttacggttc & 62 & 850 \\
\hline & FTC6 & Antisense & atgaattctggggcagaaataccg & & \\
\hline \multirow[t]{2}{*}{$S 24 \mathrm{~b}^{\mathrm{v}}$} & S24S1 & Sense & gcaacgcacagcaatatcag & 62 & 539 \\
\hline & $\mathrm{S} 24 \mathrm{~A} 1$ & Antisense & tcgtcatccgtgtatagggc & & \\
\hline \multirow[t]{2}{*}{$S 26^{x}$} & FTC14 & Sense & gaagatgccatacgcaatgg & 55 & 193 \\
\hline & FTC9 & Antisense & atgaattcttaataccgaatattggcc & & \\
\hline
\end{tabular}

2Primers designed based on sequence information from Sassa et al. (1996).

y Primers designed based on sequence information from Katoh et al. (1997).

xPrimers designed based on sequence information from Verdoodt et al. (1998).

${ }^{\text {w}}$ Verdoodt et al. (1998) reported that under these conditions, another $S$-allele that is presumed to be $S 4$ is amplified yielding a PCR product the same size as S27. After Taq1 digestion, the $S 4$ fragment is split into bands of about 190 and 90 base pairs, which can be discriminated from $S 27$ digestion products that consist

vPrimers designed based on sequence information from GenBank (accession number AFO16920).

"Primers and conditions for these $S$-alleles were published in Broothaerts et al. (1995), Janssens et al. (1995), 
(Table 1), and extension $\left(1 \mathrm{~min}\right.$ at $\left.72^{\circ} \mathrm{C}\right)$. The PCR conditions for $S \mathrm{~d}$ - and $S$ f-alleles were optimized using DNA from 'Delicious' and 'Fuji', respectively. 'Gala' (S2S5), 'Golden Delicious' (S2S3), 'Jonathan' (S7S9), 'Braeburn' (S9S24), 'Baskatong' (S26S27), 'Delicious' (S9Sd) and 'Fuji' (S9Sf) were used as positive or negative controls. The PCR products were separated on $2 \%$ agarose gels. After staining with ethidium bromide, gels were observed and photographed under ultraviolet light.

Reciprocal crosses between 'Golden Delicious' and 'Jonathan', determined to be $S 2 S 3$ and $S 7 S 9$, respectively (Janssens et al., 1995), were made in the orchard at Geneva to confirm segregation of $S$-genotypes. Blossoms were not bagged but were emasculated at the balloon stage. Two flowers were emasculated and pollinated per cluster and any nonpollinated blossoms were removed. Seeds were stratified at $2{ }^{\circ} \mathrm{C}$ for 3 months, placed at room temperature until radicle growth was observed, and then planted in an artificial soil mix.

\section{Results and Discussion}

S-genotyping of apple cultivars and selections. The apple cultivars and selections examined were either of interest in breeding or for genetic studies. $S$-genotypes determined for each of the cultivars/selections analyzed are presented in Table 2 . The $S$-genotype of 'Northern Spy' (S3Sf) was the same as that of its sport, 'Red Spy' (S3Sf), supporting research showing sports to be cross-incompatible with the original cultivar (Ishiyama et al., 1995; Way, 1995; Yamada et al., 1971). 'Melrose' (S9Sd) has the same $S$-genotype as 'Delicious', and these cultivars were reported to be cross-incompatible based on controlled hybridizations (Way, 1995).

In most cases, the $S$-genotypes corresponded with the presumed parents. However, in four cases the data indicated that the accepted pedigree is incorrect (Table 2). 'Honeycrisp' and 'Kent' have $S$-alleles different from those predicted by their reported parentage. 'Honeycrisp' ( $S 2 S 24)$ is listed as resulting from a cross of 'Macoun' $\left(S 3 S^{*}\right)$ by 'Honeygold' $\left(S 2 S^{*}\right)$, yet neither parent has the $S 24$-allele (Table 2). The $S$-genotype of 'Kent' was determined to be $S 3 S 9$ by Janssens et al. (1995) and verified in this study, but its parents are listed as 'Cox's Orange Pippin' (S5S9) and 'Jonathan' (S7S9) (Alston and Watkins, 1975). Neither parent could have contributed the S3-allele, suggesting that 'Jonathan' is not the pollen parent. The other two cases in which $S$-genotypes contradicted established pedigrees are discussed below.

The $S$-alleles of 15 Japanese cultivars had been previously determined using the allelespecific PCR and protocols for $S 2, S 3, S 5, S 7$, and $S 9$ (Sakurai et al., 1997). Seven of these 15 cultivars had an unknown allele. The new primers were tested on these cultivars and the unknown allele was determined to be $S 24$ in 'Akane' and 'Beni No Mai', and Sf in 'Fuji', 'Hokuto', and 'Senshu' (Table 2). Previously unknown alleles were also identified in the

Table 2. $S$-allele genotyping and parentage of cultivars and selections.

\begin{tabular}{|c|c|c|c|c|c|}
\hline Cultivar/selection & $S$-genotype & Seed parent & $S$-genotype & Pollen parent & $S$-genotype \\
\hline Akane & $S 7 S 24$ & Jonathan & $S 7 S 9^{\mathrm{z}, \mathrm{y}}$ & Worcester Pearmain & $S 24 S^{* \mathrm{x}}$ \\
\hline Amanishiki & $S \mathrm{fS} *$ & Ralls Janet & $\bar{S} \underline{S \mathrm{ff}}$ & Indo & $\overline{\text { No data }}$ \\
\hline Ambitious & $S 2 S 9$ & Toko & No data & Unknown & \\
\hline Beni No Mai & $S 7 S 24^{\mathrm{w}}$ & Fuji & $S 9 S f$ & Unknown & \\
\hline Cameo & $S 2 S \mathrm{~d}$ & Unknown & & Unknown & \\
\hline Empire & $S \mathrm{~d} S^{*}$ & McIntosh & $\underline{S^{*}} S^{*}$ & Delicious & $S 9 \underline{S \mathrm{~d}}$ \\
\hline Freedom & $S 5 S^{*}$ & NY 18492 & $\overline{\text { No data }}$ & NY 49821-46 & No data \\
\hline Fuji & $S 9 S f$ & Ralls Janet & $S 2 \underline{S f}$ & Delicious & $\underline{S 9 S \mathrm{~d}}$ \\
\hline Ginger Gold & $S 3 S \mathrm{~d}$ & Unknown & & Unknown & \\
\hline Golden Supreme & $S 3 S \mathrm{~d}$ & Unknown & & Unknown & \\
\hline Goldrush & $S 2 S \mathrm{~d}$ & Golden Delicious & $\underline{S 2} S 3^{\mathrm{z}}$ & Co-op 17 & No data \\
\hline Hacnine (triploid) & S3S9Sf & Fuji & $\underline{S 9} \underline{S f}$ & Tsugaru & No data \\
\hline Hokuto (triploid) & $S 7 S 9 S \mathrm{f}^{\mathrm{w}}$ & Fuji & $\overline{S 9} \underline{S f}$ & Mutsu & $S 2 S 3 S^{*}$ \\
\hline Honeycrisp & $S 2 S 24^{\mathrm{w}}$ & Macoun & $\overline{S 3} \overline{S^{*}}$ & Honeygold & $\underline{S 2} S^{*}$ \\
\hline Kent & $S 3 S 9^{\mathrm{zw}}$ & $\begin{array}{l}\text { Cox's Orange } \\
\text { Pippin }\end{array}$ & $S 5 \underline{S 9}$ & Jonathan & $S 7 S 9^{\mathrm{z}}$ \\
\hline Kitanosachi & $S 7 S^{*}$ & Tsugaru & No data & $\begin{array}{l}\text { American Summer } \\
\text { Pearmain }\end{array}$ & $S f \underline{S^{*}}$ \\
\hline Korei & S3Sde & Golden Delicious & $S 2 S \underline{3}^{\mathrm{z}}$ & Indo & No data \\
\hline Liberty & S3S5 & Macoun & $S 3 S^{*}$ & P54-12 & No data \\
\hline McIntosh & $S^{*} S^{*}$ & Unknown & & Unknown & \\
\hline Melrose & $S 9 S \mathrm{~d}$ & Jonathan & $S 7 \underline{S 9^{\mathrm{z}}}$ & Delicious & $S 9 \underline{S d e}$ \\
\hline Murasaki & $S 9 S \mathrm{~d}$ & Jonathan & $S 7 \overline{S 9}^{\mathrm{z}}$ & Delicious & $S 9 \underline{S \mathrm{de}}$ \\
\hline Nebuta & $S 3 S 9$ & Kitakami & No data & Tsugaru & No data \\
\hline North Queen & S3Sf & Fuji & $S 9 \underline{S f}$ & Tsugaru & No data \\
\hline Northern Spy & $S 3 S f$ & Unknown & & Unknown & \\
\hline NY 489 & $S 3 S 9$ & NW Greening & No data & Delicious & $\underline{S 9 S \mathrm{~d}}$ \\
\hline NY 65707-19 & $S^{*} S^{*}$ & Spartan & $S 9 \underline{S^{*}}$ & NY 55140-9 & No data \\
\hline NY 674 & $S 3 S^{*}$ & Golden Delicious & $S 2 \underline{S 3}^{z}$ & Monroe & $S 7 \underline{S^{*}}$ \\
\hline NY 73334-35 & $S 3 S 5 S 9$ & Liberty & $\underline{S 3} \underline{S 5}$ & Delicious & $\underline{S 9 \overline{S d}}$ \\
\hline NY 75413-30 & $S 3 S 5 S \mathrm{~d}$ & Liberty & $\underline{S 3} \underline{S 5}$ & Delicious & $\overline{S 9} \underline{S \mathrm{~d}}$ \\
\hline NY 75414-1 & $S 5 S^{*}$ & Liberty & $\overline{S 3} \underline{S 5}$ & Macspur & $\underline{S^{*}} \overline{S^{*}}$ \\
\hline NY 79507-72 & $S 3 S \mathrm{~d}$ & Empire & $\underline{S \mathrm{~d}} \overline{S^{*}}$ & Redfree & $\underline{S 3} S 7$ \\
\hline NY 79510-91 & $S 7 S^{*}$ & Empire & $\overline{S d} \underline{S *}$ & NY 70712-53 & $\overline{\text { No data }}$ \\
\hline Orei & $S 2 S \mathrm{~d}$ & Golden Delicious & $\underline{S 2} \overline{S 3^{z}}$ & Delicious & $S 9 \underline{S \mathrm{~d}}$ \\
\hline Red Spy & S3Sf & $\begin{array}{l}\text { Sport of Northern } \\
\text { Spy }\end{array}$ & $\underline{S 3} \underline{S f}$ & $\mathrm{NA}^{\mathrm{u}}$ & \\
\hline Redfree & S3S7 & Raritan & No data & PRI 1018-101 & No data \\
\hline Rome Beauty & S24S* & Unknown & & Unknown & \\
\hline $\begin{array}{l}\text { Russian sdlg. } \\
\text { (R12740-7A) }\end{array}$ & $\mathrm{S}^{*} \mathrm{~S} *$ & Unknown & & Unknown & \\
\hline Senshu & S7Sf & Toko & No data & Fuji & $S 9 \underline{S f}$ \\
\hline Shamrock & $\mathrm{S} 2 \mathrm{~S} *$ & McIntosh & $\underline{S^{*}} S^{*}$ & Golden Delicious & $\underline{S 2} \overline{S 3^{z}}$ \\
\hline Shinsei & S3S5 & Golden Delicious & $\overline{S 2} \underline{S 3}^{\mathrm{z}}$ & Early McIntoshw & $\overline{\text { No data }}$ \\
\hline Spartan & S9S* & McIntosh & $\underline{S^{*}} \overline{S^{*}}$ & Unknown & \\
\hline Spigold (triploid) & S2S3Sf & Red Spy & $\underline{S 3} \underline{S f}$ & Golden Delicious & $\underline{S 2 S 3^{z}}$ \\
\hline Spijon & S3S7 & Red Spy & $\underline{S 3} S f$ & Monroe & $\underline{S 7} S^{*}$ \\
\hline Suncrisp & $\mathrm{S} 3 \mathrm{~S} *$ & NJ 303955 & $\overline{\text { No data }}$ & Golden Delicious & $\overline{S 2} \underline{S 3}^{\mathrm{z}}$ \\
\hline Tohoku \#2 & S24S* & McIntosh & $\underline{S^{*}} S^{*}$ & Worcester Pearmain & $\underline{S 24 \mathrm{~S}} *$ \\
\hline Toyo & S5Sd & Delicious & $\overline{S 9} \underline{S \mathrm{~d}}$ & Unknown & \\
\hline White Angel & S5S* & Unknown & & Unknown & \\
\hline
\end{tabular}

${ }^{2}$ Determined by Janssens et al. (1995) and verified by Sakurai et al. (1997).

${ }^{\mathrm{y}} S$-allele that is underlined is the allele contributed to the offspring.

${ }^{x} S^{*} ; S$-allele unknown, $S$-allele is not $S 2, S 3, S 4, S 5, S 7, S 9, S 24, S 26, S 27, S \mathrm{~d}$, or $S f$.

${ }^{\text {w }} S$-genotype contradicts that suggested by the presumed parents.

${ }^{\mathrm{v}}$ sdlg. = seedling.

${ }^{\mathrm{N}} \mathrm{NA}=$ not applicable; cultivar/selection is a bud mutation.

parents of these Japanese cultivars, including $S 24$ in 'Worcester Pearmain', $S d$ in 'Delicious', and $S$ f in 'Ralls Janet' (Table 2). The $S$ genotype of 'Beni No Mai' (S7S24) indicates that 'Fuji' (S9Sf) was not its seed parent.

S-genotypes of 'Ginger Gold', 'Goldrush', and 'Honeycrisp'. 'Ginger Gold', 'Goldrush', and 'Honeycrisp' were determined to be $S 3 S \mathrm{~d}$, $S 2 S$ d, and $S 2 S 24$, respectively (Table 2). Pollination tests were conducted to clarify the $S$ genotype designation (Table 3). Crosses between cultivars presumed to have the same $S$ genotype often failed to set fruit. However, 'Superchief Delicious' $x$ 'Goldrush' and 'Redgold' $x$ ‘Honeycrisp' produced little fruit set, although their $S$-genotypes were different. These results emphasize the problem of pollination tests to determine incompatibility. Tests must be repeated over several years and the sometimes deleterious effects of emasculation must be considered in the design of crosses.

S-genotypes of 'Akane', 'Kitanosachi', and 'Monroe'. These three cultivars were first assigned the genotype $S 7 S 24$ using the primers designed according to Verdoodt et al. (1998). 'Akane' x 'Kitanosachi' and the reciprocal cross averaged $12 \%$ fruit set. 'Monroe' $X$ 'Akane' produced $37.8 \%$ fruit set (Table 3). Although these three cultivars were all designated $S 7 S 24$, the occurrence of fruit set sug- 
gests that an error in $S$ genotyping may have occurred. Hence, new primers for the S24allele, designated $S 24 \mathrm{~S} 1$ and $S 24 \mathrm{~A} 1$, were designed based on the $S 24$-allele sequence provided by GenBank (Table 1). Allele-specific PCR was performed again on these three cultivars using these primers. 'Akane' produced a predictive band for the $S 24$-allele. However, 'Kitanosachi' and 'Monroe' did not produce the PCR products. Therefore, the $S$ genotype of 'Akane' was determined to be S7S24 and 'Kitanosachi' and 'Monroe' had the $S 7$-allele and an unknown $S$-allele. These unknown $S$-alleles of 'Kitanosachi' and 'Monroe' are probably identical, because 'Monroe' did not fertilize 'Kitanosachi' (Table 3). However, the existence of distinct $S$-alleles with a high degree of homology is a possibility.

S-genotyping of triploid cultivars and selections. Two triploids, 'Hacnine' and 'Spigold', were determined to be $S 3 S 9 S f$ and S2S3Sf, respectively (Table 2). 'Hacnine' was reported to be a hybrid of 'Fuji' ( $S 9 S f)$ by 'Tsugaru' (Watanabe et al., 1990), and 'Spigold' resulted from the cross of 'Red Spy' (S3Sf) by 'Golden Delicious' ( $S 2 S 3$ ) (Way et al., 1968). The $S$-genotyping using the allelespecific PCR provided evidence that the female parent contributed the $2 \mathrm{n}$ gamete in both cultivars. This finding parallels studies on 'Jonagold' (Chyi and Weeden, 1984; Harada et al., 1993; Janssens et al., 1995; Sassa et al., 1994) that identified the seed parent as the contributor of the $2 \mathrm{n}$ gamete. Controlled pollination tests showed that 'Hacnine' (S3S9Sf) was cross-incompatible with both 'Fuji' ( $S 9 S \mathrm{Sf})$ and 'North Queen' (S3Sf) (Watanabe et al., 1990), and 'Spigold' (S2S3Sf) was not compatible with 'Golden Delicious' (S2S3) (Ishiyama et al., 1995). These test results support the proposed genotypes.

Two breeding selections, NY 73334-35 and NY 75413-30, both hybrids of 'Liberty' (S3S5) by 'Delicious' (S9Sd), were determined to be triploid (Table 2). Their $S$-genotypes were $S 3 S 5 S 9$ and $S 3 S 5 S \mathrm{~d}$, respectively, suggesting that both arose from an unreduced gamete of 'Liberty'. Because their pollen could fertilize other apple cultivars, these selections were initially believed to be diploid. However, examination of breeding records revealed poor fruit set in crosses involving both selections, and their seedlings resembled aneuploids. Their large fruit size, large leaves, and strong growth suggest triploid vigor.

Classifying of cultivars and selections by S-genotype. With $11 \mathrm{~S}$-alleles established (Table 1), 55 cross-incompatibility groups are possible. There are additional $S$-alleles that need to be defined, so the actual number of groups will be greater than 55 . The diploid cultivars and selections classified have been placed into only 21 groups (Table 4 ) and eight of these groups have only one cultivar assigned. The $S 3 S 9$ group had the largest number of diploid cultivars and selections (five) and also had three triploid cultivars and selections, 'Jonagold', NY73334-35, and 'Hacnine', with both $S 3$ and $S 9$ (Table 2). $S 2 S 9, S 3 S 7$, and $S 3 S \mathrm{~d}$ were the next largest groups, with four clones each.

Table 3. Controlled pollination tests of apple cultivars in 1997.

\begin{tabular}{|c|c|c|c|c|c|c|c|}
\hline $\begin{array}{l}\text { Seed } \\
\text { parent }\end{array}$ & $\begin{array}{c}\text { Proposed } \\
S \text {-genotype }\end{array}$ & $\begin{array}{l}\text { Pollen } \\
\text { parent }\end{array}$ & $\begin{array}{c}\text { Proposed } \\
S \text {-genotype }\end{array}$ & $\begin{array}{c}\text { No. flowers } \\
\text { pollinated }\end{array}$ & $\begin{array}{c}\text { No. } \\
\text { fruit set }\end{array}$ & $\begin{array}{l}\text { Fruit } \\
\text { set }(\%)\end{array}$ & $\begin{array}{r}\text { No. seeds } \\
\text { per fruit }\end{array}$ \\
\hline \multicolumn{8}{|l|}{ Golden } \\
\hline Supreme & $S 3 S \mathrm{~d}$ & Ginger Gold & $S 3 S \mathrm{~d}$ & 126 & 0 & 0.0 & --- \\
\hline Kent & $S 3 S 9$ & Ginger Gold & $S 3 S \mathrm{~d}$ & 117 & 18 & 15.4 & 7.9 \\
\hline \multicolumn{8}{|l|}{ Superchief } \\
\hline Delicious & $S 9 S \mathrm{~d}$ & Ginger Gold & $S 3 S \mathrm{~d}$ & 124 & 17 & 13.7 & 6.5 \\
\hline Goldrush & $S 2 S \mathrm{~d}$ & Redgold & $S 2 S 9$ & 119 & 36 & 30.3 & 6.5 \\
\hline Orei & $S 2 S \mathrm{~d}$ & Goldrush & $S 2 S \mathrm{~d}$ & 133 & 0 & 0.0 & --- \\
\hline Redgold & $S 2 S 9$ & Goldrush & $S 2 S \mathrm{~d}$ & 109 & 36 & 33.0 & 7.0 \\
\hline \multicolumn{8}{|l|}{ Superchief } \\
\hline Delicious & $S 9 S \mathrm{~d}$ & Goldrush & $S 2 S \mathrm{~d}$ & 110 & 8 & 7.3 & 4.6 \\
\hline Honeycrisp & $S 2 S 24$ & Redgold & $S 2 S 9$ & 113 & 30 & 26.5 & 7.5 \\
\hline Honeycrisp & $S 2 S 24$ & Tohoku \#4 & $S 9 S 24$ & 110 & 17 & 15.5 & 6.9 \\
\hline Redgold & $S 2 S 9$ & Honeycrisp & $S 2 S 24$ & 121 & 5 & 4.1 & 4.3 \\
\hline Tohoku \#4 & $S 9 S 24$ & Honeycrisp & $S 2 S 24$ & 108 & 43 & 39.8 & 9.4 \\
\hline Akane & $S 7 S 24$ & Kitanosachi & $S 7 S^{*}$ & 114 & 12 & 10.5 & 9.6 \\
\hline Kitanosachi & $S 7 S^{*}$ & Akane & $S 7 S 24$ & 129 & 17 & 13.2 & 7.4 \\
\hline Monroe & $S 7 S^{*}$ & Akane & $S 7 S 24$ & 135 & 51 & 37.8 & 7.7 \\
\hline Monroe & $S 7 S^{*}$ & Kitanosachi & $S 7 S^{*}$ & 116 & 0 & 0.0 & --- \\
\hline
\end{tabular}

Table 4. Classification of diploid cultivars and selections by $S$-genotype.

\begin{tabular}{|c|c|}
\hline$S$-genotype & Cultivar \\
\hline$\overline{S 2 S 3}$ & Golden Delicious $^{2}$ \\
\hline$S 2 S 5$ & $\mathrm{Gala}^{2}$ \\
\hline$S 2 S 7$ & $\operatorname{Arlet}^{2}$, Orin $^{y}$ \\
\hline$S 2 S 9$ & Ambitious, Kinsei $^{\mathrm{y}}$, Megumi $^{\mathrm{y}}$, Redgold ${ }^{\mathrm{y}}$ \\
\hline$S 2 S 24$ & Honeycrisp \\
\hline$S 2 S \mathrm{~d}$ & Cameo, Goldrush, Orei \\
\hline$S 2 S \mathrm{f}$ & Ralls Janet \\
\hline S3S5 & Elstar, Liberty, Shinsei \\
\hline S3S7 & Idared $^{z}, K_{\text {Kogetsu }}^{y}$, Redfree, Spijon \\
\hline$S 3 S 9$ & Kent $^{2}$, Nebuta, NY 489, Sayaka ${ }^{y}$, Sekai-ichi ${ }^{y}$ \\
\hline$S 3 S \mathrm{~d}$ & Ginger Gold, Golden Supreme, Korei, NY 79507-72 \\
\hline$S 3 S \mathrm{f}$ & North Queen, Northern Spy \\
\hline$S 5 S 7$ & Sansa $^{y}$ \\
\hline$S 5 S 9$ & Cox’s Orange Pippin \\
\hline$S 5 S \mathrm{~d}$ & Toyo \\
\hline$S 7 S 9$ & Himekami $^{y}$, Jonathan ${ }^{z}$ \\
\hline$S 7 S 24$ & Akane, Beni No Mai \\
\hline$S 7 S f$ & Amanishiki, Senshu \\
\hline$S 9 S 24$ & Braeburn $^{x}$, Tohoku \#4 \\
\hline$S 9 S \mathrm{~d}$ & Delicious, Melrose, Murasaki \\
\hline$S 9 S \mathrm{f}$ & Fuji \\
\hline
\end{tabular}

Table 5. Segregation for $S$-alleles in crosses between 'Golden Delicious' and 'Jonathan'.

\begin{tabular}{|c|c|c|c|c|c|c|c|c|}
\hline \multirow{2}{*}{$\begin{array}{l}\text { Cross } \\
\text { (S-genotype) }\end{array}$} & \multirow{2}{*}{$\begin{array}{c}\begin{array}{c}\text { No. of } \\
\text { seedlings }\end{array} \\
\end{array}$} & \multicolumn{5}{|c|}{ No. of seedlings tested (\%) } & \multirow[b]{2}{*}{$\chi^{2 z}$} & \multirow[b]{2}{*}{ Significance } \\
\hline & & Total & $S 2 S 7$ & $S 2 S 9$ & $S 3 S 7$ & $S 3 S 9$ & & \\
\hline $\begin{array}{l}\text { Golden Delicious } \\
\text { x Jonathan } \\
(S 2 S 3 \times S 7 S 9)\end{array}$ & 111 & $105(100)$ & $18(17)$ & $23(22)$ & $28(27)$ & $36(34)$ & 6.73 & NS \\
\hline $\begin{array}{l}\text { (Jonathan } \\
\times \text { Golden Delicious) } \\
(S 7 S 9 \times S 2 S 3)\end{array}$ & 33 & $25(100)$ & $9(36)$ & $4(16)$ & $6(24)$ & $6(24)$ & 2.04 & NS \\
\hline
\end{tabular}

${ }^{2}$ Chi-square tests were adjusted to compensate for having three degrees of freedom.

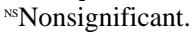

Distribution of $S$ alleles among cultivars. The origin of the $S 2$ - and/or the $S 3$-allele in many cultivars was 'Golden Delicious' ( $S 2 S 3)$, which has been used widely in breeding (Janick et al., 1996). The use of 'Jonathan' and 'Delicious' in breeding may account for the prevalence of genotypes with either $S 7, S 9$, or $S \mathrm{~d}$ alleles. The large acreage of 'Delicious' and
'Golden Delicious' in the United States appears to be reflected in the genotypes of chance seedlings. 'Ginger Gold' (S3Sd), 'Golden Supreme' $(S 3 S \mathrm{~d})$, and 'Cameo' $(S 2 S \mathrm{~d})$ are all chance seedlings with the suspected parents being 'Golden Delicious' ( $S 2 S 3)$ and 'Delicious' $(S 9 S \mathrm{~d})$.

Six out of 10 cultivars with the Sf-allele 
were Japanese cultivars and descendants of 'Ralls Janet' ( $S 2 S f)$, but this cultivar did not originate in Japan. 'Ralls Janet' was first noted in Virginia in the early 17 th century. It was thought to be a chance seedling, but some argued that it was brought to America from France (Beach et al., 1905). Both 'Fuji' (S9Sf), a hybrid of 'Ralls Janet' $x$ 'Delicious', and 'Ralls Janet' have been used widely in apple breeding in Japan to impart good fruit quality, late ripening, and long storage.

Although $S$-genotypes appear to be diverse in apple, artificial selection or use of the same cultivars as parents could restrict the number of compatibility groups. Noiton and Alspach (1996) examined genetic diversity in apple clones used in breeding and found that $64 \%$ of 439 cultivars and selections studied were descended from only five founding clones: 'Cox's Orange Pippin' (S5S9), 'Golden Delicious' (S2S3), 'Delicious' (S9Sd), 'Jonathan' (S7S9), and 'McIntosh' $\left(S^{*} S^{*}\right)$. Careful consideration of pedigrees and an increased genetic base were suggested for future apple breeding.

Controlled crosses to determine segregation of S-genotypes. 'Golden Delicious' $\mathrm{x}$ 'Jonathan' and its reciprocal cross produced 111 and 33 seeds, respectively, of which 105 and 25 were studied (Table 5). Both parents are heterozygous for the pale green lethal $(P G L)$ gene (Way et al., 1976; Yoshida et al., 1964) and $25 \%$ of the seedlings died due to PGL. Therefore, DNA from 6 and 8 seedlings in the 'Golden Delicious' $x$ 'Jonathan' and its reciprocal cross, respectively, could not be extracted before they died.

In cross-compatible pollination, each $S$ allele of the parents is presumed to have an equal probability of being transmitted to the offspring. However, in sweet cherry (Prunus avium L.) certain $S$-alleles $(S 1, S 2, S 3)$ were found to have a strong selective advantage, and selection on economic characters was suggested (Williams and Brown, 1956). In our controlled pollination tests, the segregation of $S$-genotypes did not differ significantly from the expected 1:1:1:1 ratio (Table 5). This result is in agreement with results reported by Manganaris and Alston (1987) and Batlle et al. (1995).

The information obtained on incompatibility alleles in apples will be useful in planning breeding strategies, controlled hybridizations, and orchard designs to ensure adequate pollination. Development of primers to detect new $S$-alleles will further our understanding of the incompatibility system in apple, and may allow us to examine whether self-fertility alleles exist within this system.

\section{Literature Cited}

Alston, F.H. and R. Watkins. 1975. Two new Malling apple varieties, Kent and Suntan. Rpt. East Malling Res. Sta. for 1974, p. 143-146.

Batlle, I., F.H. Alston, and K.M. Evans. 1995. The use of the isoenzymic marker gene Got-1 in the recognition of incompatibility $S$ alleles in apple. Theor. Applied Genet. 90:303-306.

Beach, S.A., N.O. Booth, and O.M. Taylor. 1905. The apples of New York. Vol. I. J.B. Lyon Company Printers. Albany, N.Y.

Broothaerts, W., G.A. Janssens, P. Proost, and W.F Broekaert. 1995. CDNA cloning and molecular analysis of two self-incompatibility alleles from apple. Plant Mol. Biol. 27:499-511.

Chyi, Y.S. and N.F. Weeden. 1984. Relative isozyme band intensities permit the identification of the $2 \mathrm{n}$ gamete parent of triploid apple cultivars. HortScience 19:818-819.

Frankel, R., E. Galun, and H.F. Linskens. 1977. Allogamy, p. 67. In: R. Frankel, E. Galun, and H.F. Linskens (eds.). Pollination mechanisms, reproduction and plant breeding. SpringerVerlag, New York.

Harada, T., K. Matsukawa, T. Sato, R. Ishikawa, M Niizeki, and K. Saito. 1993. DNA-RAPDs detect genetic variation and paternity in Malus. Euphytica 65:87-91.

Ishiyama, M., H. Kitayama, T. Sato, K. Ishizawa, Y. Nakamura, C. Suzuki, and M. Yamada. 1995. Field pollination tests in apple (in Japanese with English summary). Bul. Aomori Apple Expt. Sta. 28:1-21.

Janick, J., J.N. Cummins, S.K. Brown, and M. Hemmat. 1996. Apples, p. 1-76. In: J. Janick and J.N. Moore (eds.). Fruit breeding. Vol. II Tree and tropical fruits. Wiley, N.Y.

Janssens, G.A., I.J. Goderis, W.F. Broekaert, and W. Broothaerts. 1995. A molecular method for $S$-allele identification in apple based on allelespecific PCR. Theor. Appl. Genet. 91:691-698.

Katoh, N., K. Yamada, A. Kasai, M. Senda, K. Miyairi, and T. Okuno. 1997. cDNA cloning of apple S-RNase. Jpn. Soc. Biosci. Biotech. Agrochem. 71 (Suppl.):236.

Kobel, F., P. Steinegger, and J. Anliker. 1939. Weitere Untersuchungen uber die Befruchtungsverhaltnisse der Apfel- und
Birnsorten.Landw Jahrb. Schweiz. 53:160-191.

Komori, S., J. Soejima, Y. Ito, and H. Bessho. 1996. Analysis of $S$-allele genotypes of Japanese apple cultivars. HortScience 31:618. (Abstr.).

Manganaris, A.G. and F.H. Alston. 1987. Inheritance and linkage relationships of glutamate oxaloacetate transaminase isozymes in apple. 1. The gene Got-1, a marker for the $S$ incompatibility locus. Theor. Appl. Genet. 74:154-161.

Noiton, D.A.M. and P.A. Alspach. 1996. Founding clones, inbreeding, coancestry, and status number of modern apple cultivars. J. Amer. Soc. Hort. Sci. 121:773-782.

Sakurai, K., S.K. Brown, and N.F. Weeden. 1997. Determining the self-incompatibility alleles of Japanese apple cultivars. HortScience 32:12581259.

Sassa, H., N. Mase, H. Hirano, and H. Ikehashi. 1994. Identification of self-incompatibility-related glycoproteins in styles of apple (Malus $\times$ domestica). Theor. Appl.Genet. 89:201-205.

Sassa, H., T. Nishio, Y. Kowyama, H. Hirano, T. Koba, and H. Ikehashi. 1996. Self-incompatibility $(S)$ alleles of the Rosaceae encode members of a distinct class of the T2/S ribonuclease superfamily. Mol. Gen. Genet. 250:547-557.

Verdoodt, L., A. Van Haute, I.J. Goderis, K. De Witte, J. Keulemans, and W. Broothaerts. 1998. Use of the multi-allele self-incompatibility gene in apple to assess homozygosity in shoots obtained through haploid induction. Theor. Appl. Genet. 96:294-300.

Watanabe, H., S. Tanaka, S. Hosogai, T. Minegishi, F. Matsui, H. Muramatsu, and M. Kakizaki. 1990. New apple cultivar 'Hacnine' (in Japanese with English summary). Bul. Hokkaido Prefectural Agr. Expt. Sta. 60:87-98.

Way, R.D. 1995. Pollination and fruit set of fruit crops. Cornell Coop. Ext. Info. Bul. 237.

Way, R.D., R.L. Labelle, and J. Einset. 1968. Jonagold and Spigold. Two new apples from Geneva. Res. Circ. 12, New York Agr. Expt. Sta., Cornell Univ.

Way, R.D., R.C. Lamb, C. Pratt, and J.N. Cummins. 1976. Pale green lethal gene in apple clones. J. Amer. Soc. Hort. Sci. 101:679-684.

Williams, W. and A.G. Brown. 1956. Genetic response to selection in cultivated plants: Gene frequencies in Prunus avium. Heredity 10:237245 .

Yamada, M., C. Suzuki, M. Ishiyama, T. Sato, Y. Nakamura, and K. Ishizawa. 1971. Fruit set by cross- or self-pollination in apple (in Japanese). Tohoku Agr. Res. 12:282-285.

Yoshida, Y., S. Tsuchiya, and T. Haniuda. 1964. Frequency of the albino seedling in some cross combinations of apples (in Japanese with English summary). J. Jpn. Soc. Hort. Sci. 33:93-95. 